\title{
Pengaruh Kebijakan Subsidi Pupuk terhadap Produksi Gula Kristal Putih Indonesia
}

\section{(The Effect of Fertilizer Subsidy Policy on the Production of Indonesian Plantation White Sugar)}

\author{
Aditya Arief Rachmadhan ${ }^{1 *}$, Nunung Kusnadi ${ }^{1)}$, Andriyono Kilat Adhi ${ }^{1)}$ \\ 1) Magister Sains Agribisnis Departemen Agribisnis Institut Pertanian Bogor Jl. Kamper Wing 4 \\ Level 3 Kampus IPB Dramaga Bogor \\ E-mail: aditcakep.tq@gmail.com
}

\begin{abstract}
The direction of government policy is to increase plantation white sugar production. The government through the Ministry of Agriculture has launched fertilizer subsidies to support increased plantation white sugar production. Nevertheless, Indonesia's plantation white sugar production tends to experience a decline from year to year. This condition is not in line with the objectives. This study aims to evaluate the fertilizer subsidy policy in order to achieve the national plantation white sugar self-sufficiency target. The study uses multiple linear regression methods with time series data. The results of the analysis show that the application of the subsidized fertilizer policy does not significantly affect the production of plantation white sugar from sugar cane farmers. The area of sugarcane plantation is a factor that significantly influences the production of Indonesian plantation white sugar.
\end{abstract}

Keywords: plantation white sugar, production, fertilizer subsidy

DOI: http://dx.doi.org/10.25181/jaip.v8i1.1266

Diterima: 14 Juni 2019 / Disetujui: 10 Desember 2019 / Diterbitkan: 11 Mei 2020

\section{PENDAHULUAN}

Gula merupakan salah satu komoditas strategis dalam kerangka ekonomi pertanian nasional. Komoditas gula berperan dalam pemenuhan kebutuhan pokok dan kalori bagi masyarakat dan pemenuhan kebutuhan bahan baku industri (Wibowo, 2012). Berdasarkan Peraturan Presiden Republik Indonesia nomor 71 tahun 2015, gula telah ditetapkan sebagai salah satu barang kebutuhan pokok. Gula menjadi komoditas terpenting kedua setelah beras (Kurniasari, Darwanto, \& Widodo, 2015).

Produksi gula dalam negeri semakin tidak mampu memenuhi kebutuhan konsusmsi masyarakat (Sa'diyah, Muhaimin, \& Suhartini, 2014). Konsumsi gula terus meningkat karena meningkatnya jumlah penduduk dan semakin berkembangnya industri. Ketidakseimbangan produksi dengan konsumsi gula di Indonesia menimbulkan keharusan bagi pemerintah untuk mengimpor gula (Pujitiasih, Arifin, \& Situmorang, 2014). Perkembangan impor gula Indonesia selama periode tahun-tahun terakhir memiliki pola yang cenderung meningkat (Desideria, 2014). Ketidakseimbangan produksi dan konsumsi gula Indonesia digambarkan pada Gambar 1. 


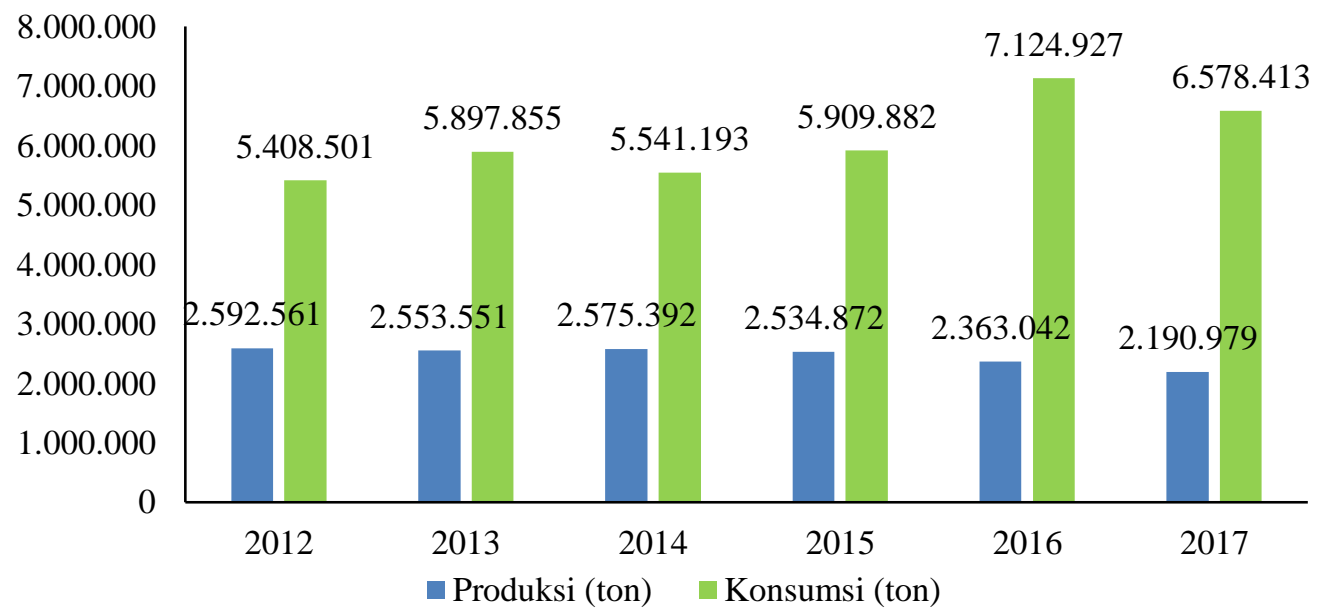

Gambar 1. Produksi dan konsumsi gula Indonesia tahun 2012 - 2017

Konsumsi gula Indonesia berasal dari konsumsi gula kristal rafinasi dan gula kristal putih. Gula kristal rafinasi merupakan gula kebutuhan industri yang diolah dari bahan baku gula mentah (dari impor). Sedangkan gula kristal putih digunakan untuk pemenuhan konsumsi rumah tangga (Fajrin, Hartono, \& Waluyati, 2015). Konsumsi gula kristal putih menempati prioritas pertama dibandingkan jenis gula lainnya (Marpaung, Hutagaol, Limbong, \& Kusnadi, 2010).

Gula kristal putih dihasilkan melalui budidaya tebu dari dalam negeri. Budidaya tebu menjadi sumber utama industri gula di Indonesia (Lestari, Fauzi, Hutagaol, \& Hidayat, 2016). Industri gula berdasarkan pengusahaan dan kepemilikan tebu/gula, terbagi menjadi tebu/gula milik petani (perkebunan tebu rakyat atau TR), tebu/gula milik PG BUMN (PBN) dan tebu/gula milik PG BUMS/swasta (PBS) (Supriyati et al., 2013). Terdapat sekitar 59 pabrik gula berbasis tebu yang beroperasi di Indonesia pada tahun 2015 - 2016 (Wright \& Meylinah, 2017). Meskipun memiliki banyak pabrik gula, namun kapasitas produksinya ternyata tidak mampu memenuhi kebutuhan konsumsi gula nasional (Widiastuty \& Haryadi, 2001).

Sesuai dengan Rencana Strategis Kementerian Pertanian, pemerintah berupaya membangun sistem ketahanan pangan yang kokoh sebagai langkah menuju swasembada pangan. Arah kebijakan pemerintah adalah upaya peningkatan produksi gula. Target pemerintah adalah tercapainya kebutuhan gula kristal putih untuk memenuhi konsumsi gula rumah tangga (Kementerian Pertanian Republik Indonesia, 2015). Pemerintah telah menyiapkan berbagai peraturan sebagai payung hukum dan pedoman dalam rangka meningkatkan produksi gula kristal putih (Hermanto, 2015).

Upaya peningkatan produksi dan rendemen tebu sangat tergantung pada pemberian pupuk (Zulkarnain et al., 2017). Kebutuhan pupuk pada budidaya tebu dengan porsi terbesar menggunakan pupuk SP-36 pada bulan pertama (periode 12 bulan sebelum panen) dan pupuk NPK yang diberikan pada bulan kedua (periode 11 bulan sebelum panen) (Indrawanto et al., 2012). Sehingga, pemerintah melalui Kementerian Pertanian telah mencanangkan subsidi pupuk guna 
mendukung peningkatan produksi gula (Kementerian Pertanian Republik Indonesia, 2015). Pupuk bersubsidi diatur melalui Peraturan Presiden Republik Indonesia Nomor 77 Tahun 2005 (sebagaimana telah diubah dengan Peraturan Presiden Republik Indonesia Nomor 15 Tahun 2011 dan diperkuat dengan Peraturan Presiden Nomor 71 Tahun 2015) sebagai salah satu barang penting yang mendukung pencapaian ketahanan pangan nasional.

Pupuk bersubsidi dianggarkan dan disalurkan kepada petani sebagai konsumen akhir. Pengaturan pengadaan, jenis, jumlah, waktu (bulan), wilayah pemasaran dan harga eceran tertinggi pupuk bersubsidi diatur melalui keputusan Menteri Pertanian setiap tahunnya. Periode tahun 2012 hingga tahun 2017, kebijakan pupuk bersubsidi diatur berdasarkan Peraturan Menteri Pertanian Republik Indonesia Nomor 87/Permentan/SR.130/12/2011, Peraturan Menteri Pertanian Republik Indonesia Nomor 69/Permentan/SR.130/11/2012 dengan perubahan Peraturan Menteri Pertanian Nomor 123/Permentan/SR.130/11/2013, Peraturan Menteri Pertanian Republik Indonesia Nomor 122/Permentan/SR.130/11/2013 dengan perubahan Peraturan Menteri Pertanian Nomor 103/Permentan/SR.130/8/2014, Peraturan Menteri Pertanian Republik Indonesia Nomor 130/Permentan/SR.130/11/2014, Peraturan Menteri Pertanian Republik Indonesia Nomor 60/Permentan/SR.310/12/2015 dengan perubahan Peraturan Menteri Pertanian Nomor 59/Permentan/SR.310/12/2016, dan Peraturan Menteri Pertanian Republik Indonesia Nomor 69/Permentan/SR.310/12/2016 dengan perubahan Peraturan Menteri Pertanian Nomor 04/Permentan/SR.310/3/2017.

Kebijakan subsidi pupuk telah lama dilaksanakan dengan tujuan salah satunya adalah meningkatkan produksi gula kristal putih. Meskipun demikian, produksi gula (gula kristal putih) Indonesia cenderung mengalamai penurunan dari tahun ke tahun (ditunjukkan pada Gambar 1). Tercatat rata-rata penurunan produksi sebesar 3,257 persen setiap tahunnya pada periode tahun 2012 hingga tahun 2017. Kondisi tersebut tidak sesuai dengan tujuan kebijakan subsidi pupuk. Sehingga perlu adanya evaluasi kebijakan dalam rangka mencapai target swasembada gula kristal putih nasional.

\section{METODE PENELITIAN}

Penelitian ini menggunakan jenis data sekunder time series bulanan tahun 2012 hingga tahun 2017. Estimasi dilakukan menggunakan data time series bulanan periode tahun 2013 hingga tahun 2017. Analisis menggunakan data yang diperoleh dari Kementerian Pertanian Republik Indonesia dan Badan Pusat Statistik (BPS). Data diolah dalam model ekonometrika yang terdiri dari tiga persamaan berdasarkan pengusahaan dan kepemilikan tebu/gula. Variabel produksi gula kristal putih Indonesia sebagai variabel endogen (terikat), sedangkan kebijakan subsidi pupuk (alokasi dan harga pupuk SP-36 periode t-12); dan alokasi dan harga pupuk NPK periode t-11) diletakkan sebagai variabel eksogen (bebas). Selain itu, luas areal dan produksi gula kristal putih 
pada periode sebelumnya juga digunakan sebagai variabel eksogen guna menganalisis pengaruh kondisi periode sebelumnya terhadap produksi gula kristal putih Indonesia. Model ekonometrika kemudian diestimasi menggunakan metode regresi linier berganda (dengan $\alpha=5 \%$ ). Adapun model dalam penelitian ini adalah sebagai berikut:

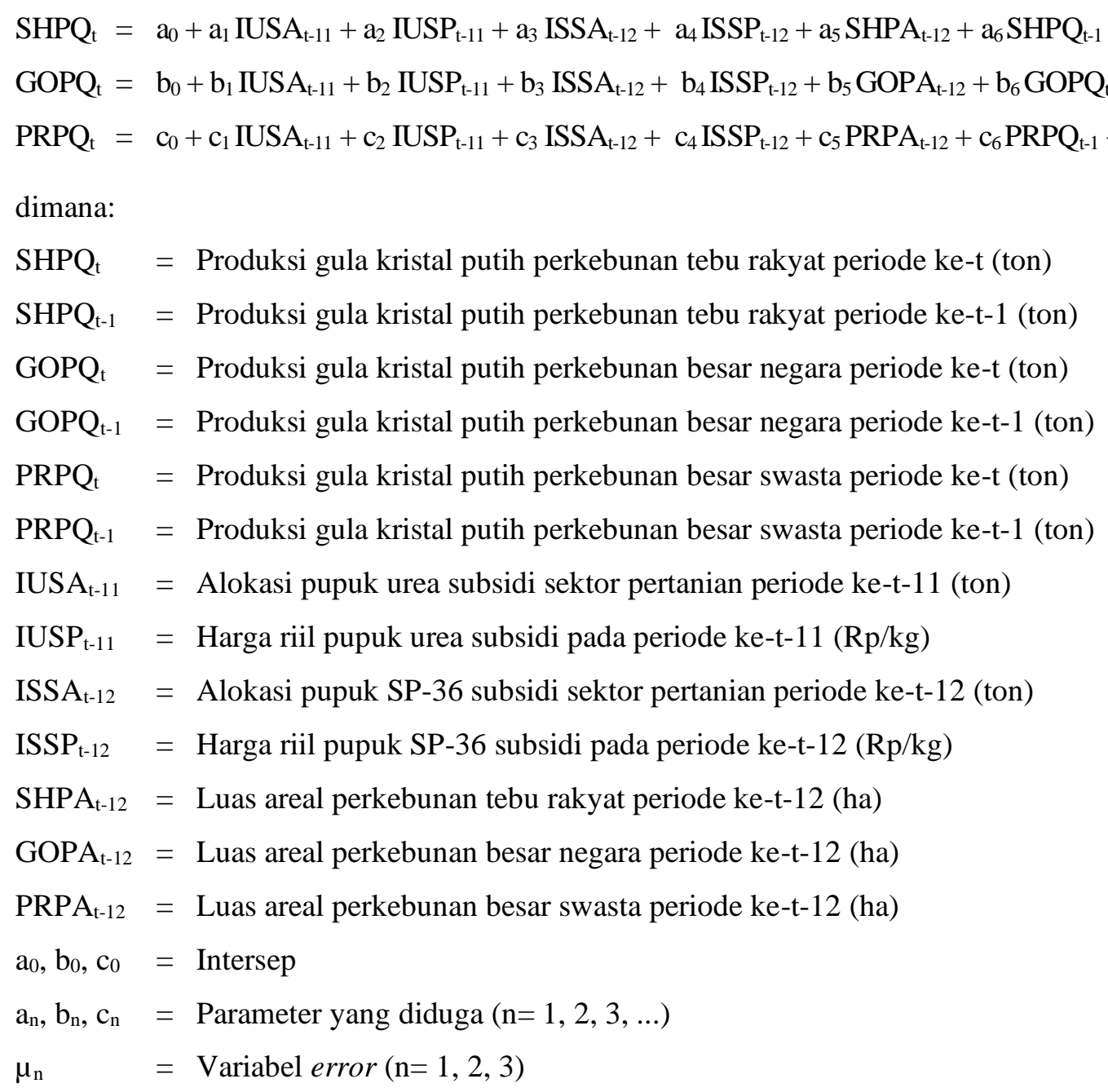

\section{HASIL DAN PEMBAHASAN}

\section{Hasil Estimasi Model}

Hasil uji stationeritas menunjukkan bahwa ketiga persamaan stationer tingkat first difference, sedangkan hasil uji kointegrasi menunjukkan bahwa nilai residual ketiga persamaan stationer (terdapat kointegrasi) pada tingkat level dengan tren waktu yang stokastik. Sehingga dengan nilai residual yang stationer (pada tingkat level), maka hasil regresi secara keseluruhan tetap valid (pada tingkat level) (Gujarati \& Porter, 2008). Hasil analisis residual menunjukkan adanya kondisi heteroskedastisitas dan autokorelasi pada persamaan $1\left(\mathrm{SHPQ}_{\mathrm{t}}\right)$ dan adanya kondisi heteroskedastisitas pada persamaan $3\left(\mathrm{PRPQ}_{\mathrm{t}}\right)$. Sehinga estimasi pada persamaan $2\left(\mathrm{GOPQ}_{\mathrm{t}}\right)$ menggunakan metode OLS, sedangkan estimasi pada persamaan $1\left(\mathrm{SHPQ}_{\mathrm{t}}\right)$ dan persamaan 3 
$\left(\mathrm{PRPQ}_{\mathrm{t}}\right)$ menggunakan metode OLS dengan melakukan koreksi terhadap standard error-nya menggunakan metode Newey-West (Gujarati \& Porter, 2008).

Tabel 1. Hasil regresi persamaan $1\left(\mathrm{SHPQ}_{\mathrm{t}}\right)$ dengan metode Newey-West

\begin{tabular}{crcc}
\hline Variabel & Koefisien & Koefisien terstandarisasi beta & Probabilitas \\
\hline C & $-21.632,190$ & & 0,563 \\
IUSA $_{\mathrm{t}-11}$ & $-0,076$ & $-0,063$ & 0,243 \\
IUSP $_{\mathrm{t}-11}$ & $-566,677$ & $-0,373$ & 0,518 \\
ISSA $_{\mathrm{t}-12}$ & $-0,370$ & $-0,069$ & 0,151 \\
ISSP $_{\mathrm{t}-12}$ & 585,647 & 0,431 & 0,461 \\
SHPA $_{\mathrm{t}-12}$ & 3,374 & 0,653 & $0,000^{*}$ \\
SHPQ $_{\mathrm{t}-1}$ & 0,308 & 0,308 & $0,000^{*}$ \\
\hline F-statistic & 88,788 & Adjusted $\mathrm{R}^{2}$ & 0,899 \\
Probabilitas F-statistic & $0,000^{*}$ & & \\
\hline Keter
\end{tabular}

Keterangan: *signifikan pada $\alpha=5 \%$

Hasil uji t persamaan $1\left(\mathrm{SHPQ}_{\mathrm{t}}\right)$ dengan koreksi terhadap standard error menggunkaan metode Newey-West (ditunjukkan pada tabel 1) menunjukkan bahwa tidak seluruh variabel eksogen berpengaruh secara signifikan terhadap variabel produksi gula kristal putih perkebunan tebu rakyat periode ke-t $\left(\mathrm{SHPQ}_{\mathrm{t}}\right)$ sebagai variabel dependen. Terdapat dua variabel yang berpengaruh secara signifikan yakni: (1) luas areal perkebunan tebu rakyat periode ke-t-12 $\left(\mathrm{SHPA}_{\mathrm{t}}\right.$ 12) dan (2) produksi gula kristal putih perkebunan tebu rakyat periode ke-t-1 (SHPQ $\left.\mathrm{t}_{\mathrm{t}-1}\right)$. Sedangkan variabel yang tidak berpengaruh secara signifikan adalah: (1) alokasi pupuk urea subsidi sektor perkebunan periode ke-t-11 (IUSA $\left.\mathrm{t}_{\mathrm{t}-11}\right)$, (2) harga riil pupuk urea subsidi pada periode ke-t-11 (IUSP $_{\mathrm{t}-11}$ ), (3) alokasi pupuk SP-36 subsidi sektor perkebunan periode ke-t-12 (ISSA $\mathrm{t}_{\mathrm{t}-12}$ ), dan (4) harga riil pupuk SP-36 subsidi pada periode ke-t-12 (ISSP $\left.\mathrm{t}_{\mathrm{t}-12}\right)$.

Tabel 2. Hasil regresi persamaan $2\left(\mathrm{GOPQ}_{\mathrm{t}}\right)$

\begin{tabular}{crcc}
\hline Variabel & Koefisien & Koefisien terstandarisasi beta & Probabilitas \\
\hline C & $-3.040,120$ & & 0,785 \\
IUSA $_{\mathrm{t}-11}$ & $-0,048$ & $-0,154$ & $0,000^{*}$ \\
IUSP $_{\mathrm{t}-11}$ & 109,425 & 0,277 & 0,511 \\
ISSA $_{\mathrm{t}-12}$ & $-0,023$ & $-0,016$ & 0,710 \\
ISSP $_{\mathrm{t}-12}$ & $-76,886$ & $-0,218$ & 0,606 \\
GOPA $_{\mathrm{t}-12}$ & 3,110 & 0,676 & $0,000^{*}$ \\
GOPQ $_{\mathrm{t}-1}$ & 0,292 & 0,293 & $0,000^{*}$ \\
\hline F-statistic & 190,519 & Adjusted $\mathrm{R}^{2}$ & 0,951 \\
Probabilitas F-statistic & $0,000^{*}$ & & \\
\hline
\end{tabular}

Keterangan: *signifikan pada $\alpha=5 \%$

Hasil uji t persamaan $2\left(\mathrm{GOPQ}_{\mathrm{t}}\right)$ (ditunjukkan pada tabel 2) menunjukkan bahwa tidak seluruh variabel eksogen berpengaruh secara signifikan terhadap variabel produksi gula kristal putih perkebunan besar negara periode ke-t $\left(\mathrm{GOPQ}_{t}\right)$ sebagai variabel dependen. Terdapat tiga variabel yang berpengaruh secara signifikan yakni: (1) alokasi pupuk urea subsidi sektor Jurnal AIP Volume 8 No. 1 | Mei 2020: 9-19 
perkebunan periode ke-t-11 (IUSA $A_{t-11}$ ), (2) luas areal perkebunan besar negara periode ke-t-12 $\left(\mathrm{GOPA}_{\mathrm{t}-12}\right)$ dan (3) produksi gula kristal putih perkebunan besar negara periode ke-t-1 $\left(\mathrm{GOPQ}_{\mathrm{t}-1}\right)$. Sedangkan variabel yang tidak berpengaruh secara signifikan adalah: (1) harga riil pupuk urea

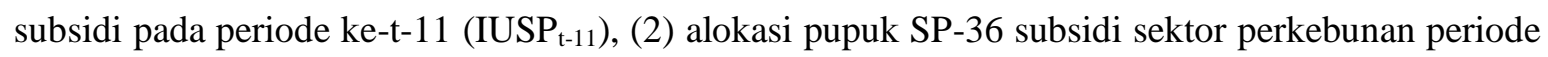
ke-t-12 (ISSA $\left.\mathrm{t}_{\mathrm{t}-12}\right)$, dan (3) harga riil pupuk SP-36 subsidi pada periode ke-t-12 (ISSP $\left.\mathrm{t}_{\mathrm{t}-12}\right)$.

Tabel 2. Hasil regresi persamaan $3\left(\mathrm{PRPQ}_{\mathrm{t}}\right)$ dengan metode Newey-West

\begin{tabular}{crcc}
\hline Variabel & Koefisien & Koefisien terstandarisasi beta & Probabilitas \\
\hline C & $-57.510,610$ & & 0,036 \\
IUSA $_{\mathrm{t}-11}$ & $-0,015$ & $-0,024$ & 0,637 \\
IUSP $_{\mathrm{t}-11}$ & 145,506 & 0,184 & 0,570 \\
ISSA $_{\mathrm{t}-12}$ & $-0,013$ & $-0,005$ & 0,927 \\
ISSP $_{\mathrm{t}-12}$ & $-680,186$ & $-0,096$ & 0,762 \\
PRPA $_{\mathrm{t}-12}$ & 5,277 & 0,852 & $0,000^{*}$ \\
PRPQ $_{\mathrm{t}-1}$ & 0,140 & 0,141 & $0,013^{*}$ \\
\hline F-statistic & 156,338 & Adjusted R & 0,940 \\
Probabilitas F-statistic & $0,000^{*}$ & &
\end{tabular}

Keterangan: *signifikan pada $\alpha=5 \%$

Hasil uji t persamaan 3 (PRPQ $)$ (ditunjukkan pada tabel 3) menunjukkan bahwa tidak seluruh variabel eksogen berpengaruh secara signifikan terhadap variabel produksi gula kristal putih perkebunan besar swasta periode ke-t $\left(\mathrm{PRPQ}_{\mathrm{t}}\right)$ sebagai variabel dependen. Terdapat dua variabel yang berpengaruh secara signifikan yakni: (1) luas areal perkebunan besar swasta periode ke-t-12 (PRPA $\left.\mathrm{P}_{\mathrm{t}-12}\right)$ dan (2) produksi gula kristal putih perkebunan besar swasta periode ke-t-1 $\left(\mathrm{PRPQ}_{\mathrm{t}-1}\right)$. Sedangkan variabel yang tidak berpengaruh secara signifikan adalah: (1) alokasi pupuk urea subsidi sektor perkebunan periode ke-t-11 (IUSA $\left.\mathrm{t}_{\mathrm{t}-11}\right)$, (2) harga riil pupuk urea subsidi pada periode ke-t-11 (IUSP $_{\mathrm{t}-11}$ ), (3) alokasi pupuk SP-36 subsidi sektor perkebunan periode ke-t-12 (ISSA $\left._{\mathrm{t}-12}\right)$, dan (4) harga riil pupuk SP-36 subsidi pada periode ke-t-12 (ISSP $\left.\mathrm{t}_{\mathrm{t}-12}\right)$.

\section{Pengaruh Alokasi Pupuk Bersubsidi terhadap Produksi Gula Kristal Putih Indonesia}

Peraturan Menteri Pertanian terkait pupuk bersubsidi menyatakan bahwa pupuk bersubsidi diperuntukkan bagi petani dan/atau petambak yang telah bergabung dalam kelompok tani. Pupuk bersubsidi tidak diperuntukkan bagi perusahaan tanaman pangan, holtikultura, perkebunan, peternakan atau perusahaan perikanan budidaya. Alokasi pupuk bersubsidi pada sektor perkebunan tebu, diperuntukkan untuk petani tebu (perkebunan tebu rakyat) guna meningkatkan produktivitas dan rendemen tebu, sehingga mendorong produksi gula kristal putih perkebunan tebu rakyat. Namun, hasil analisis menunjukkan bahwa alokasi pupuk urea subsidi dan pupuk SP-36 subsidi sektor perkebunan tidak berpengaruh secara signifikan terhadap produksi gula kristal putih perkebunan tebu rakyat. Hal ini menunjukkan bahwa kebijakan alokasi pupuk subsidi belum dapat mendorong produksi gula kristal putih perkebunan tebu rakyat. 
Hasil analisis pada kepemilikan/pengusahaan perkebunan tebu milik negara dan milik swasta menunjukkan bahwa: (1) alokasi pupuk urea subsidi dan pupuk SP-36 subsidi sektor perkebunan tidak berpengaruh secara signifikan terhadap produksi gula kristal putih perkebunan besar swasta; (2) alokasi pupuk urea subsidi sektor perkebunan berpengaruh secara signifikan terhadap produksi gula kristal putih perkebunan besar negara, namun alokasi pupuk SP-36 subsidi sektor perkebunan tidak berpengaruh secara signifikan terhadap produksi gula kristal putih perkebunan besar negara. Adanya pengaruh secara signifikan alokasi pupuk urea subsidi sektor perkebunan terhadap produksi gula kristal putih perkebunan besar negara menunjukkan perlunya penguatan pengawasan penyaluran pupuk bersubsidi.

Hasil analisis menunjukkan bahwa alokasi pupuk bersubsidi tidak seluruhnya berpengaruh secara signifikan terhadap produksi gula kristal putih di Indonesia. Meskipun demikian, hasil analisis menunjukkan bahwa seluruh koefisien alokasi pupuk bersubsidi memiliki koefisien negatif terhadap produksi gula kristal putih di Indonesia. Hal ini menunjukkan bahwa peningkatan alokasi pupuk bersubsidi tidak searah dengan pertumbuhan produksi gula kristal putih di Indonesia.

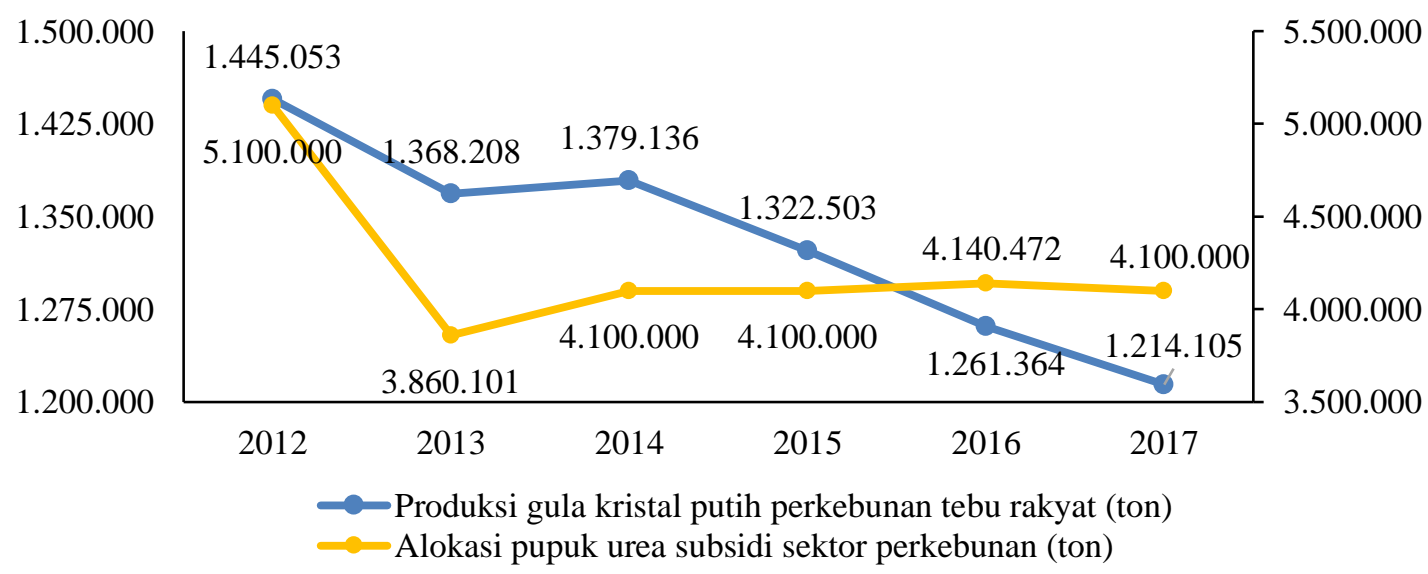

Gambar 2. Pertumbuhan produksi gula kristal putih perkebunan tebu rakyat dan alokasi pupuk urea subsidi sektor perkebunan tahun 2012-2017

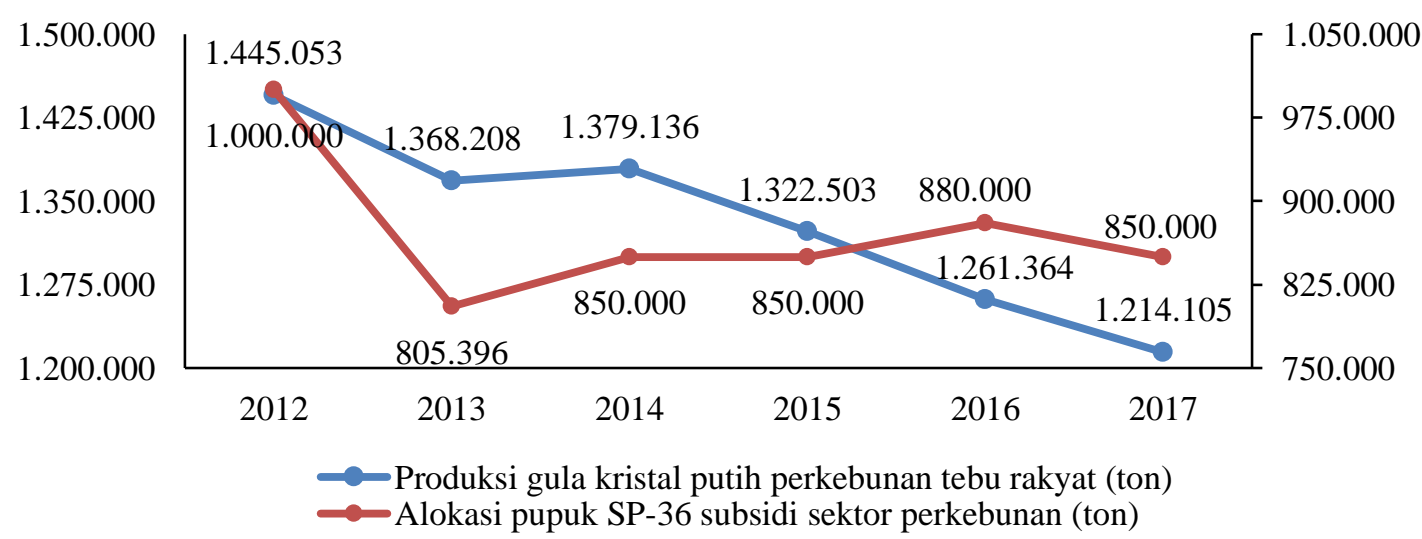

Gambar 3. Pertumbuhan produksi gula kristal putih perkebunan tebu rakyat dan alokasi pupuk SP-36 subsidi sektor perkebunan tahun 2012-2017 
Ditunjukkan pada Gambar 2 dan Gambar 3 bahwa peningkatan alokasi pupuk bersubsidi sektor perkebunan tidak searah dengan pertumbuhan produksi gula kristal putih perkebunan tebu rakyat di Indonesia. Upaya pemerintah untuk meningkatkan alokasi pupuk urea bersubsidi sektor perkebunan tidak mendorong peningkatan produksi gula kristal putih perkebunan tebu rakyat pada periode (tahun) selanjutnya. Peningkatan alokasi pupuk SP-36 bersubsidi sektor perkebunan juga tidak mendorong peningkatan produksi gula kristal putih perkebunan tebu rakyat pada periode (tahun) selanjutnya.

Petani tebu rakyat melakukan pemupukan pupuk anorganik tidak sesuai dengan dosis anjuran, dengan tujuan agar berat tebu meningkat (Nurasa \& Setiadjie, 2008). Namun penggunaan pupuk anorganik secara berlebihan dapat menurunkan hasil dan kandungan gula pada tanaman tebu. Penggunaan pupuk anorganik terus menerus menyebabkan tanah menjadi keras, masam dan pada akhirnya produksi gula kristal putih semakin rendah (Zulkarnain et al., 2017). Hal inilah yang menyebabkan peningkatan alokasi pupuk bersubsidi sektor perkebunan tidak searah dengan pertumbuhan produksi gula kristal putih perkebunan tebu rakyat di Indonesia.

\section{Pengaruh Harga Pupuk Bersubsidi terhadap Produksi Gula Kristal Putih Indonesia}

Berdasarkan hasil estimasi, diketahui bahwa harga pupuk bersubsidi seluruhnya berpengaruh secara tidak signifikan terhadap produksi gula kristal putih di Indonesia. Harga nominal (aktual) pupuk bersubsidi (periode tahun 2012 hingga tahun 2017) diatur melalui Peraturan Menteri Pertanian Republik Indonesia Nomor 87/Permentan/SR.130/12/2011, Peraturan Menteri Pertanian Republik Indonesia Nomor 69/Permentan/SR.130/11/2012, Peraturan Menteri Pertanian Republik Indonesia Nomor 122/Permentan/SR.130/11/2013, Peraturan Menteri Pertanian Republik Indonesia Nomor 130/Permentan/SR.130/11/2014, Peraturan Menteri Pertanian Republik Indonesia Nomor 60/Permentan/SR.310/12/2015, dan Peraturan Menteri Pertanian Republik Indonesia Nomor 69/Permentan/SR.310/12/2016. Selama periode tersebut, harga pupuk urea bersubsidi dan harga pupuk SP-36 bersubsidi tidak mengalami perubahan harga nominal (aktual). Harga pupuk urea bersubsidi ditetapkan sebesar Rp. 1800,00 per kilogram, sedangkan Harga pupuk SP-36 bersubsidi ditetapkan sebesar Rp. 1800,00 per kilogram. Sehingga harga pupuk bersubsidi tidak berpengaruh secara signifikan terhadap produksi gula kristal putih Indonesia.

\section{Pengaruh Luas Areal Perkebunan Tebu terhadap Produksi Gula Kristal Putih Indonesia}

Berdasarkan hasil estimasi, diketahui bahwa luas areal perkebunan tebu berpengaruh positif secara signifikan terhadap produksi gula kristal putih di Indonesia. Sehingga, peningkatan luas areal perkebunan tebu dapat memicu pertumbuhan produksi gula kristal putih Indonesia pada periode tahun selanjutnya. Sebaliknya, turunnya luas areal perkebunan tebu dapat memicu penurunan produksi gula kristal putih Indonesia pada periode tahun selanjutnya (Gambar 4). 


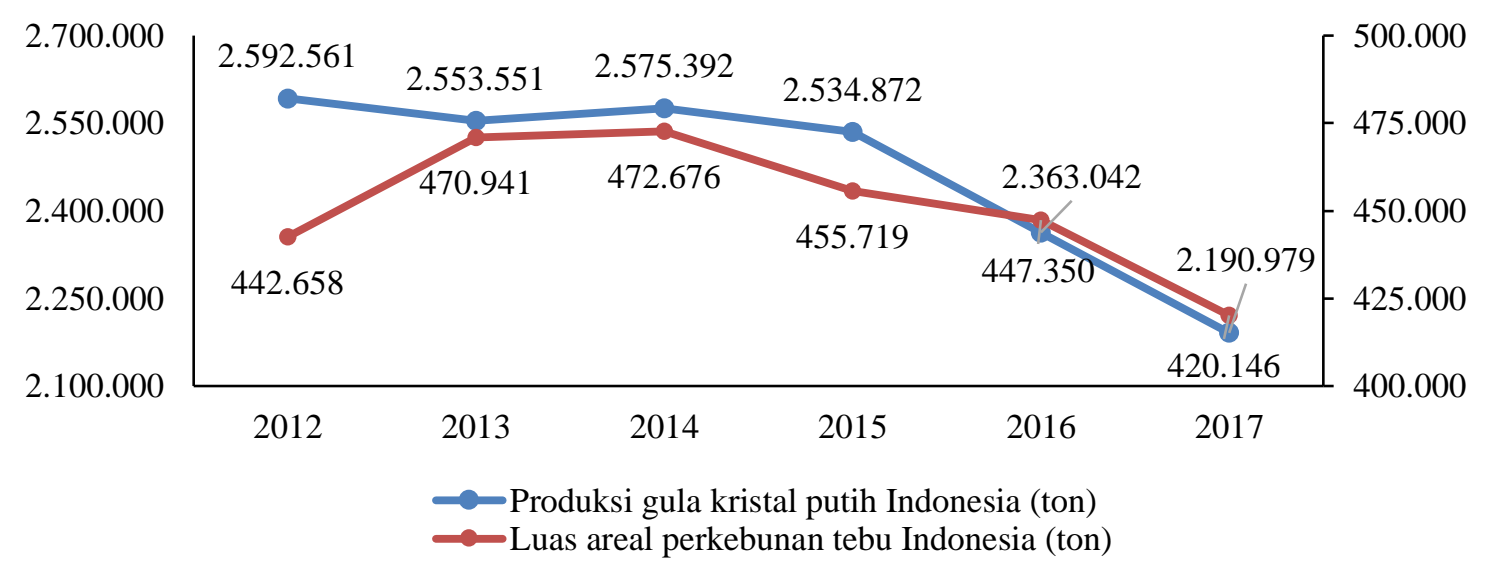

Gambar 4. Pertumbuhan produksi gula kristal putih perkebunan tebu rakyat dan alokasi pupuk SP-36 subsidi sektor perkebunan tahun 2012-2017

Hasil analisis menunjukkan bahwa luas areal perkebunan tebu memiliki nilai koefisien terstandarisasi beta bernilai positif terbesar dibandingkan dengan variabel eksogen lainnya. Hal ini menunjukkan bahwa variabel luas areal perkebunan tebu merupakan variabel yang paling berpengaruh terhadap produksi gula kristal putih Indonesia. Variabel luas areal perkebunan besar swasta periode ke-t-12 (PRPA $\left.{ }_{\mathrm{t}-12}\right)$ merupakan variabel yang berpengaruh positif dengan nilai koefisien terstandarisasi beta terbesar. Sehingga, peningkatan luas areal perkebunan tebu (ekstensifikasi) khususnya pada sektor perkebunan besar swasta merupakan upaya yang dapat ditempuh untuk meningkatkan produksi gula kristal putih Indonesia.

\section{Pengaruh Produksi Gula Kristal Putih Indonesia Periode Sebelumnya terhadap Produksi}

\section{Gula Kristal Putih Indonesia}

Berdasarkan hasil estimasi, diketahui bahwa produksi gula kristal putih periode sebelumnya berpengaruh positif secara signifikan terhadap produksi gula kristal putih di Indonesia. Hal ini menunjukkan adanya pengaruh positif yang signifikan dari produksi gula kristal putih periode sebelumnya terhadap produksi gula kristal putih di Indonesia. Turunnya produksi gula kristal putih dapat menyebabkan produksi gula kristal putih pada periode selanjutnya semakin mengalami penurunan. Sebaliknya, peningkatan produksi gula kristal putih dapat menyebabkan produksi gula kristal putih pada periode selanjutnya semakin mengalami peningkatan. Sehingga menunjukkan bahwa upaya peningkatan produksi gula kristal putih dapat memberikan dampak positif secara nyata dan berkelanjutan terhadap pertumbuhan produksi gula kristal putih di Indonesia.

\section{KESIMPULAN DAN SARAN}

\section{Kesimpulan}

Penerapan kebijakan pupuk bersubsidi tidak berpengaruh secara signifikan terhadap produksi gula kristal putih petani tebu rakyat. Hasil analisis menunjukkan bahwa alokasi dan harga Jurnal AIP Volume 8 No. 1 | Mei 2020: 9-19 
pupuk bersubsidi tidak berpengaruh terhadap produksi gula kristal putih petani tebu rakyat. Luas areal perkebunan tebu adalah faktor yang berpengaruh secara signifikan terhadap produksi gula kristal putih Indonesia.

\section{Saran}

Kebijakan pupuk bersubsidi sebaiknya tetap perlu diterapkan, dikarenakan kebijakan ini meliputi berbagai subsektor pertanian, komoditas dan pentingnya subsidi input bagi pertanian Indonesia. Pengaruh signifikan alokasi pupuk urea subsidi sektor pertanian terhadap produksi gula kristal putih perkebunan besar negara menunjukkan sebaiknya perlu adanya penguatan pengawasan pada penyaluran pupuk bersubsidi. Peningkatan produksi gula kristal putih Indonesia sebaiknya tetap mempertimbangkan upaya ekstensifikasi pertanian, terutama pada sektor perkebunan besar swasta.

\section{DAFTAR PUSTAKA}

Desideria, M. (2014). Dampak Kebijakan Ekonomi Komoditas Gula Terhadap Kesejahteraan Produsen dan Konsumen Gula di Indonesia (Institut Pertananian Bogor). Retrieved from https://repository.ipb.ac.id/handle/123456789/72787.

Fajrin, A. El, Hartono, S., \& Waluyati, L. R. (2015). Permintaan gula rafinasi pada industri makanan minuman dan farmasi di Indonesia. Agro Ekonomi, 26(2), 150-158. https://doi.org/doi.org/10.22146/agroekonomi.17267.

Gujarati, D. N., \& Porter, D. C. (2008). Basic Econometric. In Fifth Edition.

Hermanto. (2015). Stabilisasi harga pangan pokok dalam rangka kemandirian pangan nasional. In E. Pasandaran, M. Rachmat, Hermanto, M. Ariani, Sumedi, K. Suradisastra, \& Haryono (Eds.), Memperkuat Kemampuan Swasembada Pangan (pp. 136-146). Jakarta: IAARD Press.

Indrawanto, C., Purwono, Siswanto, Syakir, M., Munarso, S. J., Pitono, J., \& Rumini, W. (2012). Budidaya dan Pascapanen Tebu (1st ed.; I. M. Trisawa, Mukhasim, \& A. Budiharto, Eds.). Retrieved from http://perkebunan.litbang.pertanian.go.id/?p=20549.

Kementerian Pertanian Republik Indonesia. Peraturan Menteri Pertanian Republik Indonesia Nomor 19/Permentan/HK.140/4/2015 Tentang Rencana Strategis Kementerian Pertanian Tahun 2015-2019. , Pub. L. No. Peraturan Menteri Pertanian Republik Indonesia Nomor 19/Permentan/HK.140/4/2015 (2015).

Kurniasari, R. I., Darwanto, D. H., \& Widodo, S. (2015). Permintaan Gula Kristal Mentah Indonesia. Ilmu Pertanian, 18(1), 24-30. https://doi.org/https://doi.org/10.22146/ipas.6173.

Lestari, E. K., Fauzi, A., Hutagaol, M. P., \& Hidayat, A. (2016). Analysis of sugarcane farming in the sugar mill District Semboro Jember, Indonesia : a data envelopment analysis application. International Journal of Sciences: Basic and Applied Research (IJSBAR), 25(2), 157-171. Retrieved from http://gssrr.org/index.php?journal=JournalOfBasicAndApplied\&page=article\&op=view\&path $\% 5 \mathrm{~B} \% 5 \mathrm{D}=5165$. 
Marpaung, Y. T., Hutagaol, P., Limbong, \& Kusnadi, N. (2010). Perkembangan industri gula indonesia dan urgensi swasembada gula nasional. Indonesian Journal of Agricultural (IJAE), 2(1), 97-119. Retrieved from https://ejournal.unri.ac.id/index.php/IJAE/article/view/1500/1475.

Nurasa, T., \& Setiadjie, I. (2008). Dampak Kebijakan Perdagangan Gula Terhadap Profitabilitas Usahatani Tebu: Kasus di Kabupaten Klaten, Jawa Tengah. Buletin Ilmiah Litbang Perdagangan, 2(2), 264-286. https://doi.org/http://dx.doi.org/10.30908/bilp.v2i2.176.

Pemerintah Republik Indonesia. Peraturan Presiden Republik Indonesia Nomor 77 Tahun 2005 Tentang Penetapan Pupuk Bersubsidi Sebagai Barang Dalam Pengawasan., Pub. L. No. Peraturan Presiden Republik Indonesia Nomor 77 Tahun 2005 (2005).

Pemerintah Republik Indonesia. Peraturan Presiden Republik Indonesia Nomor 15 Tahun 2011 Tentang Perubahan Peraturan Presiden Nomor 77 Tentang Penetapan Pupuk Bersubsidi Sebagai Barang Dalam Pengawasan., Pub. L. No. Peraturan Presiden Republik Indonesia Nomor 15 Tahun 2011 (2011).

Pemerintah Republik Indonesia. Peraturan Presiden Republik Indonesia Nomor 71 Tahun 2015 Tentang Penetapan dan Penyimpanan Barang Kebutuhan Pokok dan Barang Penting., Pub. L. No. Peraturan Presiden Republik Indonesia Nomor 71 Tahun 2015 (2015).

Pujitiasih, H., Arifin, B., \& Situmorang, S. (2014). Analisis Posisi dan Tingkat Ketergantungan Impor Gula Kristal Putih dan Gula Kristal Rafinasi Indonesia di Pasar Internasional. Jurnal $\begin{array}{llll}\text { Ilmu-Ilmu Agribisnis } & \text { (JIIA), 2(1), 32-37. }\end{array}$ https://doi.org/http://dx.doi.org/10.23960/jiia.v2i1.32-37.

Sa'diyah, C., Muhaimin, A. W., \& Suhartini. (2014). Faktor-faktor yang mempengaruhi kinerja ekonomi gula kristal di Indonesia. Habitat, $X X V(2)$, 70-77. Retrieved from https://habitat.ub.ac.id/index.php/habitat/article/view/143

Supriyati, Susilowati, S. H., Ashari, Maulana, M., Saputra, Y. H., \& Suhartini, S. H. (2013). Laporan Akhir Kajian Kebijakan dan Peraturan Perundang-undangan Industri Gula Untuk Mendukung Swasembada Gula. Retrieved from pse.litbang.pertanian.go.id/ind/pdffiles/LHP_SPY_2013.pdf\%0A\%0A.

Wibowo, R. (2012). Ekonomi gula Indonesia: prospek industri berbasis tebu. In Bayu Krisnamurthi (Ed.), Ekonomi Gula (pp. 1-15). Jakarta: PT Gramedia Pustaka Utama.

Widiastuty, L. K., \& Haryadi, B. (2001). Analisa pemberlakuan tarif gula di Indonesia. Manajemen Dan Kewirausahaan.

Wright, T., \& Meylinah, S. (2017). USDA Foreign Agricultural Service Global Agricultural Information Network (GAIN) Report 13 April 2017. Retrieved from https://gain.fas.usda.gov/Recent GAIN Publications/Sugar Annual_Jakarta_Indonesia_4-132017.pdf.

Zulkarnain, E., Evizal, R., Lumbanraja, J., Rini, M. V., Satgada, C. P., Agustina, W., ... Awang, T. R. (2017). Aplikasi Pupuk Anorganik dan Organitrofos pada Tebu (Sacharum officinarum L.) di Lahan Kering Gedong Meneng. Jurnal Penelitian Pertanian Terapan, 17(1), 77-84. Retrieved from http://repository.lppm.unila.ac.id/1723/. 